Poema divulgado em folheto a $23 / 3 / 45$, pela União dos Trabalhadores Intelectuais (UTI), republicado no Correio da Manhã, de 29/3/45 e em $O$ Jornal, na mesma data.

\title{
Carlos Drummond de Andrade
}

Mal foi amanhecendo no subúrbio as paredes gritaram: anistia.

Rapidos trens chamando os operários em suas portas cruéis também soavam anistia, anistia.

Os bondes vinham cheios. Taboletas já não diziam Muda, Méier, Barcas. Uma palavra so, nelas gravada: anistia.

Os jornaleiros brandem um papel de dez metros de alto por cinqüenta. Nesse cartaz imenso, em tinta rubra: anistia.

Já as lojas pararam de vender. Os vidros, os balcões se rebelando beijam teu nome, roçam tua imagem, anistia.

Se olho para as rosas: anistia. Para os boeiros da City, para os céus, para os montes em pé nas altas nuvens: anistia.

Anistia nos becos, nos quartéis, nas mesas burocráticas, nos fornos, na luz, na solidão: só anistia.
E bate um sino. Um remo corta $a$ onda. Alguém corre na praia. Estes sinais querem dizer apenas, sem disfarce, anistia, anistia.

A sorte corre hoje. Último número. Compro o bilhete. Para decifra-lo, não preciso de códigos. Avisa-me: anistia.

Anistia: teu nome se dispersa no vento de Ipanema e do Leblon para condensar, sopro ternissimo, sobre todas as casas: anistia.

Esta é a voz dos mortos sob o marmore, é a voz dos vivos no batente. Ouço mil bocas em silêncio, murmurando: anistia.

E ouço as pedras na rua, ouço os insetos, ouço os andaimes, ouço os guardachuvas, ouço tudo rangendo, reclamando anistia.

Vem, pois, 6 liberdade, com teu fogo $e$ tua rosa rebelde nos cabelos. vem trazer os irmáos para o sol puro $e$ incendiar - de amor - os brasileiros. 